\title{
REPORT FROM THE INSIDE: THE CERD COMMITTEE'S REVIEW OF THE FORESHORE AND SEABED ACT 2004
}

\author{
Claire Charters* and Andrew Erueti*
}

\begin{abstract}
This paper describes, from the perspective of the advocates for Māori claimants, the substance of submissions to, and process followed by, the United Nations Committee on the Elimination of Racial Discrimination in determining that the Foreshore and Seabed Act 2004 discriminates against Māori. The paper has a number of functions: it illustrates that, contrary to the Prime Minister's suggestions, the process followed by the Committee was robust; provides much needed comment on the Committee's early warning and urgent action procedure; should be useful to other individuals or groups seeking to challenge legislation in international fora; and, finally, sheds light on the Committee's succinct decision by placing it within the context from which it emerged.
\end{abstract}

\section{INTRODUCTION}

In July 2004 the Taranaki Māori Trust Board, Te Runanga o Ngai Tahu and the Treaty Tribes Coalition (the Claimants) requested that the Committee on the Elimination of Racial Discrimination (the Committee) invoke its early warning and urgent action procedure to review the Foreshore and Seabed Bill (FS Bill). ${ }^{1}$ Eight months later, in March 2005, the Committee determined that New Zealand's Foreshore and Seabed Act 2004 (FSA) discriminates against Māori (the CERD Decision) under the Convention on the Elimination of All Forms of Racial Discrimination (the Convention). ${ }^{2}$

The CERD Decision is unique for New Zealand in a number of ways. It is only the second time a United Nations human rights treaty body has found New Zealand in breach of a human rights treaty outside of the state reporting process. ${ }^{3}$ It is the first time New Zealand has been criticised by

* Ngati Whakaue. Lecturer, Faculty of Law, Victoria University of Wellington.

** Nga Ruahinerangi. Lecturer, Faculty of Law, Victoria University of Wellington.

1 Foreshore and Seabed Bill 2004, no 129-1.

2 International Convention on the Elimination of All Forms of Racial Discrimination (4 January 1969) 660 UNTS 195.

3 The first time was in Rameka $v$ New Zealand (15 December 2003) CCPR/C/79/D/1090/2003. 
an international human rights tribunal for breaching the human rights of its indigenous peoples. ${ }^{4}$ In addition, it is the first time that the Government has responded negatively to a decision of an international tribunal.

Of the many criticisms levelled at the Committee and the CERD Decision by the Government, one related to the process followed by the Committee. The Prime Minister stated: ${ }^{5}$

This is a committee on the outer edges of the UN system. It is not a court. It did not follow any rigorous

process as we would understand one. In fact, the process itself would not withstand scrutiny at all.

In the light of the Government's process-based concerns with the CERD Decision and both the exceptional nature of, and lack of published material about, the early warning and urgent action procedure, the principal purpose of this report on the CERD Decision is to describe the process leading to that decision. In this sense, it focuses on the means as well as the ends. We hope that our perspective as advocates for the Claimants sheds a light on that process that would not be immediately obvious from a review of the written material available. We hope, also, that this paper will be useful to other individuals and groups who seek to challenge New Zealand bills or legislation on human rights grounds, especially given that there are no domestic avenues available to seek an enforceable decision overturning bills or legislation in New Zealand. Finally, as the CERD Decision is short it is necessary to place it within the context and the arguments from which it emerged to understand it properly.

Our structure is as follows: in the following part we describe the Convention and the function of the Committee. In part three we explain the basis of the claim to the Committee and the submissions made by the Claimants and the Government. This illustrates that the Committee heard advanced and nuanced legal submissions and provides the requisite backdrop to explain the process followed, which is described in part four. In part five, we deconstruct the CERD decision in the light of the previous sections, comment on the Government's reaction to it and examine its possible ramifications.

\section{INTERNATIONAL CONVENTION ON THE ELIMINATION OF ALL FORMS OF RACIAL DISCRIMINATION, THE COMMMITTEE AND MONITORING OF STATES}

The Convention came into force in $1969 .{ }^{6}$ Its focus, as its name suggests, is on the abolition of racial discrimination. ${ }^{7}$ Under article 5 state parties undertake to guarantee that all members of the

4 There is one communication to the Human Rights Committee brought by Māori individuals arguing a breach of their rights as Māori. However, the majority of the Human Rights Committee found that New Zealand was not in breach of human rights. See Apirana Mahuika V New Zealand (27 October 2000) $\mathrm{A} / 56 / 40$.

5 Interview with Rt Hon Helen Clark, Prime Minister (John Dunne, Breakfast Show TRN 3ZB, 14 March 2005) Transcript provided by Newztel News Agency Ltd (Wellington). 
state will enjoy all human rights on an equal footing. In total, 170 countries have ratified the Convention. New Zealand ratified it in 1972.

The Committee is made up of 18 independent experts who are elected by secret ballot from states' nominations. ${ }^{8}$ The Committee monitors states' compliance with the Convention in four ways. First, state parties report periodically on their compliance with the Convention and receive comments and recommendations on their reports from the Committee. ${ }^{9}$ New Zealand has participated in this process since it ratified the Convention. Secondly, the Committee has a state-tostate complaints procedure, whereby a state may challenge another state's compliance with the Convention. ${ }^{10}$ Third, the Committee will hear complaints, called communications, from individuals about states, but only if the state in question declares that it recognises the competence of the Committee to do so. New Zealand has not made that declaration, although the Committee has encouraged it to do so. ${ }^{11}$ Finally, in 1993, the Committee developed the early warning and urgent procedure, which will be discussed in more detail below. ${ }^{12}$

Significantly, the Committee has emphasised that the protections in the Convention extend to indigenous peoples. In 1992, the Committee issued a General Recommendation in relation to Indigenous Peoples (General Recommendation on Indigenous Peoples), noting its concern about the

6 International Convention on the Elimination of All Forms of Racial Discrimination, above n 2.

7 International Convention on the Elimination of All Forms of Racial Discrimination, above $\mathrm{n} 2$, art 1(1). The full article states: "racial discrimination" shall mean any distinction, exclusion, restriction or preference based on race, colour, descent, or national or ethnic origin which has the purpose or effect of nullifying or impairing the recognition, enjoyment or exercise, on an equal footing, of human rights and fundamental freedoms in the political, economic, social, cultural or any other field of public life.

8 International Convention on the Elimination of All Forms of Racial Discrimination, above n 2, art 8(2).

9 International Convention on the Elimination of All Forms of Racial Discrimination, above n 2, art 9.

10 International Convention on the Elimination of All Forms of Racial Discrimination, above n 2, art 11.

11 The Committee has, in its Concluding Observations on New Zealand's Compliance with the Convention, expressed the hope that New Zealand would consider making a declaration under article 14 of the Convention so that individuals could lodge complaints with CERD. In response to this, the New Zealand Government stated that it was not considering making an "article 14 declaration" because "it had accepted a broadly based complaints procedure under the Optional Protocol to the International Covenant on Civil and Political Rights." See UN Committee on the Elimination of Racial Discrimination "Concluding Observations of the Committee on the Elimination of Racial Discrimination: New Zealand" (22 September 1995) A/50/18, para 416.

12 The UN Secretary-General and other agents within the UN advised all human rights bodies to inquire into early warning procedures that would seek to prevent disputes from escalating into wide-scale conflict and avoid human rights violations. The Committee, in response to that call, adopted a working paper on the prevention of racial discrimination, including early warning and urgent procedures: UN Committee on the Elimination of Racial Discrimination "Working Paper on Early Warning and Urgent Action Procedures" (1993) A/48/18, Annex 3. That paper has formed the basis of the Committee's procedure. 
lingering effects of colonial discrimination on indigenous peoples, the loss of their lands and resources and continuing discrimination. ${ }^{13}$ In particular, the General Recommendation on Indigenous Peoples calls on states to: ${ }^{14}$

$[R]$ ecognise and protect the rights of indigenous peoples to own, develop, control and use their communal lands, territories and resources and, where they have been deprived of their lands and territories traditionally owned or otherwise inhabited or used without their free and informed consent, to take steps to return those lands and territories. Only when this is for factual reasons not possible, the right to restitution should be substituted by the right to just, fair and prompt compensation. Such compensation should as far as possible take the form of lands and territories.

The Committee's concern in relation to the treatment of indigenous peoples was illustrated clearly when in August 1999 it invoked the early warning procedure to request that the Australian Government suspend the operation of the discriminatory amendments to the Native Title Act 1993 (the Australian Native Title Decision). ${ }^{15}$

\section{THE BASIS OF THE CLAIM TO THE COMMITTEE AND ARGUMENTS PRESENTED}

The following section describes the background to the FSA, and summarises the Claimants' and Government's arguments before the Committee.

\section{A Basis of the Claim}

\section{Ngati Apa}

The New Zealand Court of Appeal decision in Ngati Apa v Attorney General (Ngati Apa) concerned the jurisdiction of the Māori Land Court. ${ }^{16}$ The Māori Land Court was first established in 1865 in New Zealand to investigate who owned defined areas of tribal land according to tribal custom and then grant freehold titles to those owners. ${ }^{17}$ The Māori Land Court converted almost all that remained of customary title to dry land at the Māori Land Court's inception into freehold title by

13 The Committee, like other human rights treaty-based bodies, has initiated the practice of adopting general recommendations which refer either to the obligations of state parties arising under a specific treaty provision or issues concerning the implementation of the treaty more generally. UN Committee on the Elimination of Racial Discrimination "General Recommendation XXIII: Indigenous Peoples" (18 August 1997) A/52/18, annex V.

14 "General Recommendation XXIII: Indigenous Peoples", above n 13, annex V.

15 UN Committee on the Elimination of Racial Discrimination "Decision 2(54) on Australia" (18 March 1999) $\mathrm{A} / 54 / 18$.

16 Ngati Apa v Attorney General (Ngati Apa) [2003] 3 NZLR 143 (CA).

17 The Native Lands Act 1865 established the Native (now Māori) Land Court. 
the year $1900 .{ }^{18}$ In Ngati Apa the principal legal question was whether the Māori Land Court had the authority under its constituent statute, the Te Ture Whenua Māori Act 1993 (TTWMA), to exercise that very same jurisdiction in relation to the foreshore and seabed.

Applying well-established principles of native title law, the Court of Appeal held that customary title had survived the Crown's assertion of sovereignty in 1840 (the date of the signing of the Treaty of Waitangi between Māori and the British Crown) and that customary title had not been extinguished by general legislation. ${ }^{19}$ In addition, the Court of Appeal ruled that its previous decision in In Re the Ninety Mile Beach (Ninety Mile Beach) was wrong in law. ${ }^{20}$ That decision had effectively shut down Māori claims to customary title in the foreshore by ruling that any customary interests in foreshore and seabed were extinguished, by implication, if the adjoining dry lands were investigated by the Native Land Court, the Māori Land Court's predecessor. This idea of extinguishment of customary title by implication was firmly rejected by the Court of Appeal in Ngati Apa. ${ }^{21}$

The Court of Appeal then determined that the Māori Land Court had jurisdiction to inquire whether defined areas of foreshore and seabed had the status of "Māori customary land" (defined in TTWMA as land held by Māori in accordance with Māori customary values and practices). ${ }^{22}$ Having obtained such a determination, Māori tribes could then apply under TTWMA for the land to be converted from "Māori customary land" into "Māori freehold land",23 essentially a common law freehold title that gives titleholders the right to control access to the land and the right, subject to confirmation by the Māori Land Court, to sell the land.

In addition, the Court of Appeal's finding that any customary interests in the foreshore and seabed were not extinguished meant that Māori could claim common law native title interests in the foreshore and seabed before the High Court. Following Ngati Apa, then, Māori could advance claims to customary title via two routes: the Māori Land Court under its statutory jurisdiction; and the High Court exercising its inherent common law native title jurisdiction. It is only in respect of

18 Before, Māori Land Court customary title to dry land had been extinguished by Crown purchase and confiscation policies.

19 The effect of area-specific statutes was left for consideration by the Māori Land Court when exercising its jurisdiction.

20 In Re the Ninety Mile Beach [1963] NZLR 261 (CA)

21 Only one judge, Gault P, agreed with the legal rule in In Re the Ninety Mile Beach. See Ngati Apa V Attorney General, above n 16, 677 Gault P.

22 See Te Ture Whenua Māori Act 1993, s 129(2)(a) and the definition of "tikanga Māori ", s 4.

23 Te Ture Whenua Māori Act 1992, ss 131-132. 
the Māori Land Court however, that tribes might have acquired a freehold title. But, under the law of native title the general courts have recognised a right to exclusive occupation of dry land. ${ }^{24}$

\section{The Government's response and Māori objections}

The prospect of Māori freehold titles in the New Zealand foreshore and seabed proved too controversial for the New Zealand Government. Just days after the Ngati Apa decision, it announced that it would introduce legislation to overrule the decision. In August 2003, the Government released a policy document proposing that legislation be introduced to: declare the entire foreshore and seabed public domain; guarantee a general right of access along the foreshore; remove the Māori Land Court's jurisdiction to grant freehold titles in the foreshore and seabed (the High Court's native title jurisdiction was ignored); and establish a new Māori Land Court jurisdiction whereby it could recognise "customary rights" only in the foreshore and seabed. ${ }^{25}$ That document was disseminated widely and was the subject of meetings with Māori tribal and urban communities. Māori almost universally rejected those proposals and a later version, which fleshed out the August policy, was released in December 2003. The December policy was to provide the basis for the drafting of the Foreshore and Seabed Bill (FS Bill) introduced into Parliament early in 2004.

Aware of the speed with which the FS Bill would be prepared, in December 2003 the Waitangi Tribunal agreed to hold an urgent hearing into whether the December policy complied with the principles of the Treaty of Waitangi. At the hearing, much of the discussion focussed on how the Māori Land Court, or the High Court exercising its native title jurisdiction, might have treated claims by Māori. This was conjecture, given that the Government had made it clear that this jurisdiction would be removed, but it was necessary in order to determine whether the December policy was short-changing Māori. Most counsel pointed to the human rights implications of the proposals; for some this was the substance of their argument. ${ }^{26}$

The Waitangi Tribunal's Report on the Crown's Foreshore and Seabed Policy (Waitangi Tribunal Report), published on 4 March 2004, outlined human rights concerns with the policy and there was frequent comment on the policy undermining due process, the rule of law and being unfair, and discriminatory. ${ }^{27}$

24 See Mabo v Queensland (No 2) (1992) 175 CLR 1 (HCA); Delgamuukw v British Columbia [1997] 3 SCR 1010.

25 The Foreshore and Seabed of New Zealand: Protecting Public Access and Customary Rights (Government proposals for consultation, New Zealand Government, Wellington, 2003).

26 See for example, Submissions of A Erueti (Counsel for Wai 142, 552, 553) in reply, 2 February 2004, Doc A120.

27 Waitangi Tribunal Report on the Crown's Foreshore and Seabed Policy (Wai 1071, Legislation Direct, Wellington, 2004). The Waitangi Tribunal has the jurisdiction to determine whether governmental policy complies with the principles of the Treaty of Waitangi. See Treaty of Waitangi Act 1975, s 6. 
The FS Bill reflected the key principles in the August and December policy documents:

- the entire foreshore and seabed was to be vested in the Crown, excepting all extant freehold titles (defined as specified freehold interests) in the area;

- public access generally over the foreshore and seabed was to be guaranteed;

- the Māori Land Court's jurisdiction to grant Māori freehold titles in the foreshore and seabed was to be removed and replaced with jurisdiction to grant "customary rights orders". The circumstances in which extinguishment of customary rights would occur were outlined;

- the High Court's inherent native title jurisdiction was to be removed and replaced with jurisdiction to grant "territorial customary rights orders" (TCRs). TCRs recognised that at common law the TCR holder would have had, but for the FSA, the native title right to exclusively occupy an area of the foreshore and seabed; and

- the holders of TCRs had the right to enter into discussions with the government of the day to negotiate the possibility of redress.

On 6 May 2004 the FS Bill was referred to the Fisheries and Other Sea Related Legislation Select Committee (the Select Committee) to hear public submissions and make comment on the FS Bill. On the same day the Attorney-General reported on the FS Bill's compliance with the New Zealand Bill of Rights Act 1990 (BORA) ${ }^{28}$ She concluded that while the FS Bill might be a prima facie breach of the right to freedom from discrimination, that breach was justified under BORA in large part because the uncertainty generated by the Ngati Apa decision required legislative intervention.

The Select Committee received just fewer than 4000 submissions, of which over 94 per cent opposed the FS Bill. The opposition generally related either to concerns about denying Māori the right to pursue claims under TTWMA or under common law; or to the Crown's power to alienate the public foreshore and seabed by passing subsequent legislation. Support for the FS Bill centred on public ownership, on the access and navigation provisions, and on the protections in the FS Bill for Māori customary interests. Many of the submissions spoke about the Bill's inconsistency with domestic and international human rights law. Unfortunately however, the Select Committee was unable to reach agreement on whether the FS Bill should be passed and, if so, in what form. The

28 Attorney General "Report on the Consistency of the Foreshore and Seabed Bill with the New Zealand Bill of Rights Act 1990" (6 May 2004). 
difficulty for the Select Committee was that it was sharply divided along party lines. ${ }^{29}$ As a result, the Select Committee was unable to agree on any amendments to the FS Bill.

When the FS Bill was returned to Parliament for its second reading on 16 November 2004, the Government tabled substantial amendments by way of a Supplementary Order Paper. ${ }^{30}$ Those amendments ran to sixty-seven pages and made substantial changes to the Bill. The most significant changes:

- more tightly prescribed the tests for establishing TCRs (for example, applications for TCRs could only be made by those who owned the contiguous dry land since 1840);

- $\quad$ added a new mechanism of redress for TCR holders in the form of a foreshore and seabed reserve; and

- $\quad$ added mechanisms seeking to protect and enhance customary rights under the Resource Management Act 1991 (the RMA).

The FSA was enacted on 24 November 2004.

\section{B Arguments}

The arguments outlined here are a condensed version of the submissions made by the Claimants and the Government over the course of eight months from July 2004, when the initial claim was lodged with the Committee, up to 11 March 2005, the date of the CERD Decision.

\section{Racial discrimination under the Convention}

Under domestic and international human rights law, human rights are not absolute. Domestically, in New Zealand, the right to freedom from discrimination under the BORA, along with the other rights and freedoms in BORA, may be subject to "such reasonable limits prescribed by law as can be demonstrably justified in a free and democratic society". ${ }^{31}$ Likewise, the Committee's General Recommendation 14 notes that a differentiation will not constitute discrimination where "the criteria for such differentiation judged against the objectives and purposes of the Convention are legitimate". ${ }^{32}$

29 Foreshore and Seabed Bill 2004, no 129-1 (the commentary) 23. The deadlock resulted from the Government and the New Zealand First party members' refusal to accept the United Party member's proposal to extend the time for hearing submissions and reporting to Parliament until March 2005. A vote on this resulted in a tie, with the four Government members and one New Zealand First member voting against the extension and the other five members voting in favour.

30 Foreshore and Seabed Bill 2004, Supplementary Order Paper 2004, no 302.

31 New Zealand Bill of Rights Act 1990, s 5.

32 UN Committee on the Elimination of Racial Discrimination "General Recommendation XIV: Definition of Discrimination" (22 March 1993) A/48/18, para 2. 
Throughout the course of submissions to the Committee there was little argument by the Government as to whether the FS Bill or FSA actually discriminated against Māori. We had argued that the basis of discrimination was the difference in treatment between Māori property interests in the foreshore and seabed and the treatment of non-Māori property rights (meaning property rights not sourced in Māori customary title). In short, Māori property rights were extinguished and replaced with prescribed statutory customary rights, whereas freehold titles (specified freehold interests) in the foreshore and seabed were not affected. ${ }^{33}$ This, we argued, infringed a large number of the Convention's provisions. The Government, however, pretty much conceded that there was racial discrimination, in large part influenced by the Attorney-General's finding, in her BORA vet, of prima facie racial discrimination. The substance of the debate therefore focused on whether under the Convention this racial discrimination was justified. On this ground the Government made these key arguments: that the legislative response to Ngati Apa was necessary given the uncertainty generated by that decision; and the replacement regime for recognition of customary rights and TCRs in the FSA was fair and robust.

\section{Uncertainty generated by Ngati Apa}

After Ngati Apa, the Government consistently stressed that legislative intervention was justified by the uncertainty generated by that decision. In written submissions, and when appearing before the Committee, the Government focused on the effect of the Ngati Apa decision on the success of the marine farming industry. The hearing of Māori claims to the foreshore and seabed after Ngati Apa, it was claimed, would have halted the development of marine farming and other development and conservation activities in the foreshore and seabed. It was also said that the Ngati Apa litigation had been one of the key reasons for the imposition of a moratorium on the granting of marine farms. The Government believed therefore that the proper course was to "achieve a balance between certainty through the Crown vesting on behalf of the New Zealand public while ensuring a process for recognition and redress where a territorial customary right could be established." ${ }^{13}$

In response, we stressed that governments must have been aware for many years and well before the marine farming industry began to grow in the 1990s, that its title to the foreshore and seabed was not guaranteed. The Crown's view that it owned the foreshore was, in large part, based on Ninety Mile Beach. ${ }^{35}$ But, this case had long been considered out of step with native title law. ${ }^{36}$ It was also

33 Before the Committee we extended that idea by arguing that even if there was no difference in treatment, the FSA still discriminated against Māori as the FSA was aimed at Māori property rights and sought to diminish those rights.

34 New Zealand's submission on the Foreshore and Seabed Act 2004 to the Committee.

35 In Re the Ninety Mile Beach, above n 20.

36 See Calder v Attorney General of British Columbia [1973] SCR 313; for New Zealand see Te Weehi v Regional Fisheries Officer [1986] 1 NZLR 680 (HC); for academic commentary critical of In Re the Ninety Mile Beach see New Zealand Law Commission The Treaty of Waitangi and Māori Fisheries (NZLC PP9, 
clear, according to Ngati Apa, that no general legislation in New Zealand had extinguished customary interests in the foreshore and seabed. We also noted that the moratorium on marine farms was largely due to the shortage of suitable space for marine farming and the need to develop a coherent aquaculture regime before further development took place. ${ }^{37}$

In our view, the Government had overstated the level of uncertainty created by Ngati Apa and underestimated the ability of the courts to resolve conflicts between Māori and non-indigenous interests in the foreshore and seabed (including marine farming licences). As evidenced from other jurisdictions, this is a body of law well within the expertise of the common law courts. We emphasised that when the courts of other jurisdictions originally recognised native title rights, their governments did not rush to enact a code prescribing the types of customary rights that could be recognised by the courts and the circumstances in which those rights would be extinguished. Governments in Canada have responded by allowing tribal communities to either claim aboriginal rights in court or enter into negotiations to create a treaty to settle their claims by consent and with compensation. A similar approach applies in Australia. Following the Mabo v Queensland (No 2) (Mabo No 2) native title decision, ${ }^{38}$ the federal government decided to allow claimants to litigate their claims in the courts subject to certain private titles being validated. The Native Title Act 1993, enacted to provide a framework for hearing these claims, has in part influenced the nature of native title litigation. However, that statute does not prescribe the types of customary rights that may be recognised by the courts and the circumstances in which extinguishment of customary interests will occur. ${ }^{39}$

The New Zealand courts, we submitted, could have addressed customary claims in the same manner. There was strong support for this approach in the Waitangi Tribunal's Foreshore and Seabed Report: ${ }^{40}$

The process of court hearings, appeals, and final decisions on the extent of rights would be a slow one, as the Crown argued. The inevitably of appeals from decisions made by the lower courts limits the scope for a radical and expansionist approach to the definition of customary rights. In the meantime, private

Wellington, 1989) section 15; R P Boast "In Re the Ninety Mile Beach Revisited: The Native Land Court and the Foreshore in New Zealand Legal History" (1993) 23 VUWLR 145; F M Brookfield "The New Zealand Constitution: The Search for Legitimacy" in I H Kawharu (ed) Waitangi: Māori and Pakeha Perspectives on the Treaty of Waitangi (Oxford University Press, Auckland, 1989) 10-12; P G McHugh The Màori Magna Carta: New Zealand Law and the Treaty of Waitangi (Oxford University Press, Auckland, 1991) 117-126.

37 See Hon Pete Hodgson, Minister of Transport "Aquaculture Law To Get Much-Needed Overhaul" (28 November 2001) Press Release.

38 See Mabo v Queensland (No 2), above n 24.

39 See Native Title Act 1993 (Cth).

40 Report on the Crown's Foreshore and Seabed Policy, above n 27, 121. 
property rights would not be affected in any significant way. Anyway, change would be gradual. There would be time for the Crown to correct any problems as they arise. There may be some slowing of investment and development, but it will not be excessive or permanent. Incremental court decisions will allow regulatory regimes and private right-holders time to reach accommodations with Māori.

The Government, we argued, went far beyond what was necessary to establish the certainty it required in the FSA, just as it had done in relation to the other objectives it advanced for the FSA. In short, the FSA was a case of statutory overkill for New Zealand. All of the uncertainty, we submitted, had been imposed upon Māori under the FSA.

3 The FSA's statutory replacement regime for recognition of Màori rights in foreshore and seabed

The Government argued that the replacement regime in the FSA essentially mirrored the rights Māori could claim at common law following Ngati Apa and in fact went beyond any other jurisdiction by recognising the potential for a native title right to exclusive occupation. It was also argued that any shortcomings with the framework reflected the inherent limitations of native title as a remedy. Here, the Government's submissions focussed on the common law native title remedy and not the Māori Land Court's ability to grant freehold titles in the foreshore and seabed. The significance of the Māori Land Court's jurisdiction, especially the possibility of Māori freehold titles, was, we thought, downplayed.

The Government's argument that the FSA was more benevolent than other common law jurisdictions was a reference to the right to seek TCRs from the High Court under the FSA. As noted above, these orders recognise that the holders would have had, but for the FSA, the right under common law native title law to exclusively occupy an area of the foreshore. The remedy for such orders under the FSA is not the right to exclusively occupy the area claimed but rather the right to enter into negotiations with the government of the day for redress. TCRs, it was argued, went beyond that of any other common law jurisdiction because the Australian High Court, in Commonwealth $v$ Yarmirr (Yarmirr) ${ }^{41}$ had rejected a native title claim to exclusively occupy a defined area of the seabed in the Northern Territory of Australia. ${ }^{42}$ Here the Government relied a great deal on the expert evidence of Dr Paul McHugh who, before the Waitangi Tribunal, had speculated that if the New Zealand courts had been permitted to exercise their common law native title jurisdiction, they would have adopted the reasoning in Yarmirr. ${ }^{43}$

In response, we noted that it was far from clear that New Zealand courts would have adopted the decision in Yarmirr. Also, the Canadian courts are yet to make a ruling on this point and there is no

41 Commonwealth v Yarmirr(2001) 208 CLR 1.

42 Instead the High Court granted the claimants a bundle of rights to engage in customary activities.

43 See Report on the Crown's Seabed and Foreshore Policy, above n 27, 49 and following for the summary of Dr Paul McHugh's evidence; Dr Paul McHugh's evidence, Document A 23. 
guarantee that Yarmirr would be applied there. We argued that New Zealand's circumstances are very different from Australia's. Australia had, until the Mabo v Queensland (No 2) decision in 1992 recognising native title, been considered terra nullius or devoid of indigenous inhabitants. ${ }^{44} \mathrm{New}$ Zealand, on the other hand, had rejected that legal fiction in the first years of settlement. ${ }^{45}$

In addition, we argued that since the Mabo (No 2) decision, the Australian courts, applying the Native Title Act 1993, have adopted a very narrow approach towards the recognition of native title. This was in fact a point made by the Committee and the United Nations Human Rights Committee (UNHRC) on many previous occasions. ${ }^{46}$

That aside, the crux of our submission in relation to the FSA's replacement regime was that it tightly prescribes the customary rights that may be recognised, the standards of proof, or tests, for recognition of such rights and the circumstances in which they will have been extinguished or expired (of which there are many). We argued that the New Zealand courts should have been left, like the common law jurisdictions in Australia and Canada, to develop their own standards of proof for determining whether there was a native title right to exclusive occupation or a native title right to engage in a particular activity.

We also noted that in establishing tests for claiming customary rights and territorial customary rights orders the Government had adopted aboriginal rights concepts from Canada and Australia. We submitted that it was inappropriate to seek to transplant aboriginal title jurisprudence and standards of proof from other common law jurisdictions, relating to other aboriginal communities, to New Zealand, given the many significant constitutional differences between the jurisdictions and differences in tribal customs and social and political organisation. The importance of contextual differences and different judicial approaches to native title recognition is illustrated by the very different judicial approaches seen in Canada and Australia towards the characterisation, ${ }^{47}$ and proof, ${ }^{48}$ of aboriginal rights.

44 Mabo v Queensland (No 2), above n 24, 56 Brennan J.

45 See the Supreme Court decision of $R$ v Symonds (1847) [1840-1932] NZPCP 387.

46 "Decision (2)54 on Australia", above n 15, concluding observations/comments; see also "Concluding Observations by the Committee on the Elimination of Racial Discrimination: Australia" (19 April 2000) CERD/C/304/Add 101; See also the criticisms of the 1998 amendments to the Native Title Act 1993 made by the Human Rights Committee: "Concluding Observation of the Human Rights Committee: Australia" (24 July 2000) A/55/40.

47 The Australian High Court has characterised native title as a bundle of rights, whereby native title claimants must establish in evidence each individual right claimed, see Western Australia v Ward (2002) 191 ALR 1. The Canadian courts, on the other hand, see aboriginal title as a "right in land" whereby an underlying title supports a range of aboriginal rights, see Delgamuukw v British Columbia, above n 24.

48 In addition, these jurisdictions have adopted very different approaches towards proving native title. Canada has adopted a "factual-based approach" by focusing on the practice of specific activities prior to white 
But not only had the Government borrowed aboriginal rights concepts from other countries, it had also grafted additional more onerous requirements on to the tests. ${ }^{49}$ It was therefore odd for the Government to submit that any shortcomings with the FSA's replacement regime reflected the limitations of common law native title as a remedy.

Finally we noted that the government's submissions, especially those concerning the limitations of common law native title recognition in the foreshore, failed to acknowledge the Māori Land Court's statutory jurisdiction to investigate customary title and then grant a freehold title in the foreshore and seabed.

\section{Provision of redress}

Here, the Government stressed that the redress offered under the FSA in relation to TCRs was fair and robust. It argued that the Government could be expected to act in good faith in negotiations, as evidenced by the negotiation of historical grievances under the Treaty of Waitangi, and that "the Act provides a reasonable balance between the courts' role of identifying rights and interests and government's role in negotiating a redress package with Māori." It was stressed also that negotiations provided a means of circumventing the shortcomings of aboriginal rights litigation and that New Zealand tribes, Ngati Porou and Te Whanau-a-Apanui, were already negotiating with the Government under the FSA.

In response, we argued that there was no guaranteed right of redress, only the right to enter into discussions about the possibility of redress. The term, redress, suggested that full compensation would not be paid; in fact there is no guarantee that any redress would be provided and there is no independent mechanism for determining the nature of any redress to be provided. We noted that past

contact - to establish "aboriginal rights" to engage in particular activities, like hunting and fishing, see $R V$ Van der Peet [1996] 2 SCR 507 - and exclusive physical occupation of areas of land at sovereignty - to establish an aboriginal title to occupy land exclusively in the modern age, see Delgamuukw $V$ British Columbia, above n 24. The Australian native title jurisprudence, on the other hand, adopts a "normativebasis" for proving native title in that native title claimants must prove a continuous connection with an area of land or water that is established by a body of customary laws.

49 For example, to claim an aboriginal right in Canada to engage in an activity, the right claimed must have a reasonable degree of continuity with a practice, tradition or custom that was integral to the distinctive culture of the aboriginal people prior to contact with the Europeans: $R v_{V}$ Pamajewon [1996] 2 SCR 821; Mitchell v Minister of National Revenue [2001] 1 SCR 911. Under the FSA claimants for customary rights order must not only show that the right claimed was integral to their tikanga (customary laws) at 1840 but that the right remains so today, see Foreshore and Seabed Act 2004, s 50(1). In addition, the right claimed must have been substantially uninterrupted during that time - a more onerous requirement than the Canadian "reasonable degree of continuity" test, see Foreshore and Seabed Act 2004, s 50(1). For criticisms of the test in Canada see Leonard Rotman "Creating Still-life Out of Dynamic Objects: Rights Reductionism at the Supreme Court of Canada" (1997) 36 Alberta Law Review 1; Russell Lawrence Barsh and James Youngblood Henderson "The Supreme Court's Van der Peet Trilogy: Naive Imperialism and Ropes of Sand" (1997) 42 McGill LJ 993. 
experience with negotiations between Māori and the Crown showed that Māori had little bargaining power and were in effect forced to accept what was offered in these "negotiations". 50

We also noted that the alternative remedy of a "foreshore and seabed reserve" did not confer any property right in the tribe (the reserve remains in Crown ownership). They serve no better function than to set up a body that could prepare a "management plan" akin to "iwi management plans" prepared by tribes under the RMA identifying their special interests for the purpose of preparing RMA planning documents, consultation and granting consents. Given that tribes are already able to prepare management plans under the RMA, and no property rights are acquired or rights to control access, or compensation for non-recognition of common law rights, there seemed to be no real advantage in seeking this remedy.

Moreover, we argued that the foreshore and seabed reserve seemed to set a benchmark for these negotiations. If negotiations failed, the reserve remedy is deemed to be the only available alternative. It was therefore difficult to see these negotiations providing any remedy more fruitful than that offered by the foreshore and seabed reserve.

\section{Effective participation}

The General Recommendation on Indigenous Peoples stresses the need for indigenous peoples to participate effectively in the formulation of policy that affects them. We argued that the Government had failed to effectively consult with Māori and take their views into consideration when drafting the FSA. The foreshore and seabed proposals released in August 2003 were not in fact proposals, but rather a statement of the Government's position on the Ngati Apa case. Māori were not consulted in the formulation of those proposals and rejected them at every opportunity when the Government subsequently presented them, which is significant given that the Government did not deviate from them.

We noted also that a comparison could be made to the UNHRC decision in Mahuika $v$ New Zealand (Mahuika). ${ }^{51} \mathrm{~A}$ similar obligation of effective participation and informed consent can be found in the UNHRC's jurisprudence on article 27 of the International Covenant on Civil and Political Rights (ICCPR) guaranteeing a right to enjoy culture. ${ }^{52}$ In the Mahuika decision, the

50 A recent publication by the Crown Forestry Rental Trust on Māori experiences of the direct negotiation process notes how many Māori negotiators consider that these are not in fact negotiations, see Māori Experiences of the Direct Negotiation Process (Crown Forestry Rental Trust, Wellington, 2003). The Crown negotiators (all members of the Office of Treaty Settlements) set the parameters of the negotiations from the outset. Certain matters are not on the table for negotiation, including rights to self-government (akin to the rights conferred on indigenous peoples in the British Columbia treaty settlement process), and rights to precious minerals like oil and gas. In addition, the compensation paid in these settlements is a tiny fraction of the true economic loss suffered by tribes.

51 Apirana Mahuika v New Zealand, above n 4.

52 International Covenant on Civil and Political Rights (19 December 1966) 999 UNTS 171. 
UNHRC considered that the Treaty of Waitangi (Fisheries Claims) Settlement Act 1992 did not breach, among other articles, article 27 of the ICCPR. In reaching that conclusion, the UNHRC was influenced by the fact that there was support for the settlement from the Waitangi Tribunal (albeit qualified), the New Zealand Court of Appeal, and a broad cross-section of Māori following "a complicated process of consultation". ${ }^{53}$ The same could not be said of the FSA.

\section{International law submissions}

We made an additional argument: that international law protects indigenous peoples' land rights held under their indigenous laws, and not merely those rights capable of recognition by the common law. International law prohibits discrimination between property rights recognised under state law and property rights recognised under indigenous law. Underlying the argument was the principle that indigenous legal systems must have a status equal to that of state legal systems.

It was argued, therefore, that the FSA discriminates against Māori by not recognising Māori customary rights in the foreshore and seabed according to Māori customary law - which we argued was possible under TTWMA but not possible with the FSA's narrow statutory replacement regime while at the same time preserving non-indigenous freehold titles (specified freehold interests). In addition, in relation to justifications, we argued that the Committee, in assessing the adequacy of the FSA's replacement regime, should consider the rights Māori may have possessed under Māori customary law and then compare those rights - rather than the rights that may have been recognised by common law native title - with the FSA's replacement framework. This rendered arguments based on Yarmirr about the limitations of common law recognition of native title in the foreshore irrelevant.

We relied on a number of international instruments and jurisprudence to establish that international law protects indigenous peoples' land rights under indigenous law. They included International Labour Organisation Convention 169 on Indigenous and Tribal Peoples (ILO Convention 169) and the Draft Declaration on the Rights of Indigenous Peoples (the Draft Declaration), ${ }^{54}$ both of which contain robust guarantees of indigenous peoples' land rights. Recent Inter-American Court of Human Rights and the Inter-American Commission on Human Rights jurisprudence was most helpful. The Inter-American Court found that Nicaragua had violated the American Convention on Human Rights by failing to legally recognise and protect the communal

53 Apirana Mahuika v New Zealand, above n 4.

54 Sub-Commission on the Protection and Promotion of Human Rights Resolution 1994/45 (26 August 1994) E/CN4/1995/2; International Labour Organisation Indigenous and Tribal Peoples Convention (Convention 169, 27 June 1989). 
property rights of the indigenous Awas Tingni peoples of Nicaragua and granting a concession over Awas Tingni land without Awas Tingni consent. ${ }^{55}$ The Court stated: ${ }^{56}$

[I]t is the opinion of the Court that article 21 of the Convention protects the right to property in a sense which includes, among others, the rights of members of the indigenous communities within the framework of communal property ....

It also held that "as a result of customary practices, possession of the land should suffice for indigenous communities lacking real title to property to obtain official recognition of that property ...."57 The Inter-American Commission has been similarly progressive in decisions on indigenous peoples' rights. ${ }^{58}$ We also stressed the consistency between the Committee's own General Recommendation on Indigenous Peoples and protection of indigenous land rights under indigenous law.

One of the difficulties with the submission, raised by one of the Committee members, was that international legal instruments and jurisprudence recognising indigenous peoples' property rights under indigenous law are not binding on New Zealand. To address this issue, we argued that the

55 Mayagna (Sumo) Awas Tingni Community v Nicaragua (31 August 2001) Inter-American Court of Human Rights, No 79, series C; also published in (2002) 19 Arizona Intl and Comp Law 395. For a full description of the proceedings leading to the decision see S J Anaya and C Grossman "The Case of Awas Tingni V Nicaragua: A New Step in the International Law of Indigenous Peoples" (2002) 19 Arizona J Int'l and Comp Law 1.

56 Mayagna (Sumo) Awas Tingni Community v Nicaragua, above n 55, para 148.

57 Mayagna (Sumo) Awas Tingni Community v Nicaragua, above n 55, para 151.

58 It found the United States in breach of the right to equal treatment because it did not apply the same standard of compensation to a taking of Western Shoshone property as it applied to the taking of other property interests. Mary and Carrie Dann (27 December 2002) Inter-American Court of Human Rights, No 11.140, Report 75/02. The Commission wrote: "[Recognition of the collective aspect of indigenous rights] has extended to acknowledgment of a particular connection between communities of indigenous peoples and the lands and resources that they have traditionally owned and used, the preservation of which is fundamental to the effective realisation of human rights of indigenous peoples" para 128. Similarly, it recently found Belize in breach of rights to property, equality before the law and to judicial protection because it did not take measures to protect Maya peoples' communal rights to property under indigenous law. Maya Indigenous Communities of the Toledo District $v$ Belize (12 October 2004) Inter-American Commission of Human Rights, Report No 96/03. The Inter-American Commission wrote: "[T]he organs of the inter-American human rights system have recognised that the property rights protected by the system are not limited to those property interests that are already recognised by states or that are defined by domestic law, but rather the right to property has an autonomous meaning in international human rights law. In this sense, the jurisprudence of the system has acknowledged that the property rights of indigenous peoples are not defined exclusively by entitlements within a state's formal legal regime, but also include the indigenous communal property that arises from and is grounded in indigenous custom and traditions" para 117. 
Committee's jurisprudence should not fall below the standards set by other international instruments and institutions. 59

The Government's only real response to this argument was that Māori do not own land under custom. ${ }^{60}$ In fact, Māori do have a strong legal relationship with land under Māori customary law, it is only that the term "ownership" as understood in an English-sense is an inappropriate word to describe that relationship.

\section{PROCESS}

In this section we outline the process that led to the CERD Decision including how the Claimants lobbied the Committee to review to FS Bill and FSA in the first instance, and the means by which both the Government and Claimants presented their arguments to the Committee. As stated in the introduction, there were no clear procedural guidelines to follow, yet the Committee, in its direction of the Claimants and the Government, ensured that both parties were heard and had access to the Committee members.

\section{A Searching for an Independent Arbiter}

By July 2004, when the FS Bill was before the Select Committee, the Claimants, and others, were of the view that the FS Bill discriminated against Māori and that the discrimination in the FS Bill was unlikely to be eliminated before its enactment. The Government had ignored human rights concerns in the development of its policy, the Waitangi Tribunal's Report and the public's opposition to the FS Bill. The Claimants feared submissions to the Select Committee based on human rights would be similarly snubbed. From their perspective, the Attorney General's vet of the FS Bill was flawed. Therefore, the Claimants, like many others, assessed their options to seek persuasive and independent critical comment on the FS Bill. The possibility of such comment by an international human rights tribunal had been raised and discussed in a number of fora including in academic conferences after the Government's policies on the foreshore and seabed had been publicised. $^{61}$

59 For example, we contended that the Committee should interpret the right to freedom from discrimination in the same way as the Inter-American Court: to prohibit states treating indigenous property rights under indigenous law differently from other kinds of property rights. Not to do so would undermine evolving international law standards on indigenous peoples' land rights, also mirrored in other international instruments.

60 Tim Caughley, New Zealand Permanent Representative to the United Nations, to Mr Yutzis, Chair of the UN Committee on the Elimination of Racial Discrimination (9 March 2005) Letter.

61 See for example Andrew Erueti "The Use of International Fora to Protect Māori Property Rights in Oil and Gas and Foreshore-Seabed" (Seminar Series on "Resource Ownership and Access - Where to From Here", School of Law, Waikato University, Hamilton, 3 October 2003). Interestingly the Attorney General was present at this seminar. 
It was important to the Claimants that an international human rights tribunal find the FS Bill discriminatory before it was enacted. They had no doubt that international criticism would come eventually either through the treaty state reporting process or through a communication lodged with the UNHRC. ${ }^{62}$ But the Claimants thought that the Government would be more likely to amend the FS Bill in the light of international treaty body criticism than it would the FSA. Once the FS Bill was enacted, the view was that there was unlikely to be sufficient support in Government to remove discriminatory elements given that by then the FSA would be up and running.

The Committee's early warning and urgent action procedure seemed to offer the only real hope of censure before the FS Bill's enactment. Its very objective is to enable the Committee to respond promptly to racial discrimination, and the Committee was scheduled to meet in August 2004 before the Select Committee report-back. In contrast, the individual communication procedure under the UNHRC has historically taken many years and New Zealand was not due to present a report to the UNHRC or Committee before the end of 2004.

\section{$B$ Lobbying the Committee to Invoke its Early Warning Procedure}

The early warning and urgent action procedure was devised by the Committee itself to enable it to prevent and respond more effectively to violations of the Convention. ${ }^{63}$ The Chair of the Committee has described the process as "fluid", suggesting that the Committee is more concerned with substance than with following predetermined procedural rules. In a letter to New Zealand's Permanent Representative to the United Nations in Geneva (the Permanent Representative), he wrote that "the Committee's underlying concern is to facilitate effective implementation of the Convention." 64

That the process is flexible is perhaps not surprising given the differences in the circumstances the Committee reviews utilising the early warning and urgent action procedure. They include, for example, the crisis in Sudan's Dafur region and, as we know, indigenous peoples' land rights issues. The process must be capable of adaptation to allow the Committee to respond to these varying human rights concerns. It must also be managed to provide alleged victims of racial discrimination

62 International Covenant on Civil and Political Rights, above $\mathrm{n}$ 52. New Zealand ratified the ICCPR in March 1979 and in August 1989 had accepted the right of individuals to bring communications under the Optional Protocol to the ICCPR. That remedy would come too late however. First, we would need to show that Māori had exhausted domestic remedies and there was some doubt about that as it is possible under the Human Rights Act 1993 to seek a declaration that enacted legislation is inconsistent with section 19 of The New Zealand Bill of Rights Act. And aside from these issues, while the Human Rights Committee's response to communications has improved in recent years, it was unrealistic to expect the Human Rights Committee to hear and decide on a communication promptly.

63 Office of the High Commissioner for Human Rights $<$ http://www.ohchr.org $>$ (last accessed 31 May 2005).

64 Mr Yutzis, Chair of the UN Committee on the Elimination of Racial Discrimination, to Tim Caughley, New Zealand Permanent Representative to the United Nations (2 March 2005) Letter. 
the opportunity to be heard given that only states, formally at least, have standing to present their arguments to the Committee.

Based on research and advice from advocates for Indigenous Australians in the Australian Native Title Case, the Claimants chose to lobby the Committee by first sending it comprehensive briefs explaining the FS Bill and how it breached the Convention. For strategic reasons, the Claimants sought and received support for their briefs from numerous Māori tribes and organisations, including Te Arawa Māori Trust Board, Te Runanga o Toa Rangatira, Te Runanga o Raukawa and the Federation of Māori Authorities. ${ }^{65}$ It was important to illustrate to the Committee the degree of Māori rejection of the FS Bill and to highlight that this was not a situation where Māori had divergent views on the merits of the Government's policies as had been the case in Mahuika.

However, the Claimants had to first persuade the Committee that it was appropriate for it to invoke the early warning and urgent action procedure to review the FS Bill. The Committee's criteria for invoking its early warning procedure are not closed. However, they include: ${ }^{66}$

- a lack of adequate legislative basis for defining and criminalising all forms of racial discrimination;

- inadequate implementation of enforcement mechanisms, including the lack of recourse procedures;

- the presence of a pattern of escalating racial hatred and violence, or racial propaganda or appeals to racial intolerance by persons, groups or organisations, notably by elected or other officials;

- a significant pattern of racial discrimination evidenced in social and economic indicators; and

- $\quad$ significant flows of refugees or displaced persons resulting from a pattern of racial discrimination or encroachment on the lands of minority communities

First, we submitted that there are inadequate procedures for preventing racial discrimination in New Zealand. We pointed out that there is no objective, apolitical means by which to review draft legislation for compliance with human rights norms. We criticised the Attorney-General's vet of the FS Bill under BORA. The Attorney-General, by constitutional convention, is required to act in an independent, non-partisan manner when vetting bills for BORA compliance. Yet it seemed to us that in drafting the vet, the Attorney-General was under enormous pressure to find that the Bill was

65 See Te Runanga o Ngai Tahu and Treaty Tribes Coalition, to the UN Committee on the Elimination of Racial Discrimination (10 January 2005) Submission.

66 "Working Paper on Early Warning and Urgent Action Procedures", above n 12. 
consistent with BORA. We also disputed the Attorney-General's view that any prima facie racial discrimination was justified by the level of uncertainty created by the Ngati Apa decision for the reasons set out above.

Under this ground we also noted that once legislation is enacted in New Zealand it cannot be overturned for breaching human rights. Under the Human Rights Act 1993 (the HRA), enacted legislation may be declared by the Human Rights Review Tribunal, and later by the courts on appeal, to be inconsistent with the right to freedom from discrimination under BORA. ${ }^{67}$ However, such a declaration does not affect the validity, application or enforcement of the enactment.

Secondly, we noted a pattern of appeals to racial intolerance by, in particular, elected officials. We focused on public speeches on the foreshore and seabed and Māori rights by the Leader of the National Party, the Prime Minister, and the justice spokesperson for the ACT party. In particular, we stressed that Don Brash's high profile "Orewa speech" of January 2004 appealed to racial intolerance with its criticism of special measures for Māori in the health and education sector, the Treaty of Waitangi settlement process and references to the Treaty of Waitangi in legislation. ${ }^{68} \mathrm{We}$ also noted the large public support the National Party received following that speech and how, in response, the Government had promised to stamp out preferential policies based on race and review all statutory references to the Treaty of Waitangi. 69

Finally, we noted the concern expressed by the Committee in its observations on previous New Zealand state reports about the socio-economic circumstances of Māori, Pacific Islanders and other minorities in New Zealand, and the "disproportionately high representation of Māori and Pacific Islanders in correctional facilities." ${ }^{70}$ We suggested that much of this could be sourced in the historically discriminatory acquisition of Māori tribal land and assimilation polices pursued by successive governments. We noted that many of these policies persisted into the late twentieth century.

67 Human Rights Act 1993, s 92J; New Zealand Bill of Rights Act 1990, s 19 racial discrimination.

68 Dr Don Brash "Nationhood" (Orewa Rotary Club, 27 January 2004).

69 Hon Trevor Mallard "Terms of Reference: Review of Targeted Programmes" (25 March 2004) Press release. The Labour government has been down this road before. In the year 2000, the Labour government introduced its "Closing the Gaps" policy aimed at closing the social and economic gap between Māori and Pakeha with spending of $\$ 360$ million over four years. But the programme was rebranded "reducing inequalities" after political fallout about targeting Māori with the money.

70 See "Concluding Observations of the Committee on the Elimination of Racial Discrimination: New Zealand", above n 11, para 416. 


\section{The Committee's August Response}

During its August 2004 meeting the Committee resolved to seek further information from the Government on the allegations of racial discrimination under the FS Bill. ${ }^{71}$ On the one hand, the Claimants were pleased that the Committee had engaged with its lobbying on the papers and that it was, quite appropriately, providing the Government with the opportunity to respond. On the other, they were concerned that the FS Bill would be passed before the Committee's scheduled February/March 2005 meeting. There was some hope at that stage, which on reflection was probably naive, that the Committee would make a decision on the FS Bill on the papers and without appearances in person before its next formal meeting.

\section{$D$ Lobbying in Person}

In September 2004 we had the opportunity to meet with the Committee's institutional support person, Nathalie Prouvez, based in Geneva, while attending the United Nations Working Group on the draft Declaration on the Rights of Indigenous Peoples. ${ }^{72}$ The meeting gave us a sense of the Committee's approach to the FS Bill and the opportunity to clarify the written submissions. We understand from that meeting, also, that New Zealand's Permanent Representative to the United Nations in Geneva had also made contact with Ms Prouvez.

\section{E The Government's September Response}

On 20 September 2004 the Government formally responded to the Committee's request for information, focusing predominantly on the grounds for invoking the early warning and urgent action procedure. In relation to the claimants' arguments concerning the inadequate procedures to challenge racial discrimination, the Government noted that the Bill was under consideration by two parliamentary select committees and "will next be subject to debate and voting before Parliament as a whole". ${ }^{73}$ The Government also referred to "further means for raising human rights issues under domestic legislation and under international law once the Bill is passed". ${ }^{74}$ Here, we assume the Government was referring to the HRA process of seeking a declaration that legislation is discriminatory and the possibility of lodging communications with the UNHRC. The Government also rejected any characterisation of the current process as "racial propaganda" or "appeals to racial intolerance". Rather, the Government insisted "the debate over the Bill, within and beyond

71 UN Committee on the Elimination of Racial Discrimination "Concluding Observations on the Committee's $65^{\text {th }}$ Session" (20 August 2004) Press Release.

72 Established by United Nations Human Rights Commission, Resolution 1995/32.

73 New Zealand Government, to the UN Committee on the Elimination of Racial Discrimination (20 September 2004) Submission.

74 New Zealand Government, to the UN Committee on the Elimination of Racial Discrimination, above $\mathrm{n} 73$. 
Parliament, indicates an open process of engagement by Government with New Zealanders interested in the issues at stake". ${ }^{75}$

The Government's failure to engage, at this point, in any detail with the substantive arguments we had raised in our initial briefs was surprising. The Government simply stated that customary rights are complex, New Zealand has settled many Māori historical Treaty of Waitangi grievances, described the process of consultation leading to the Bill, outlined the purposes and the principles underlying the FS Bill, including the principle of certainty, and described the Bill. ${ }^{76}$

\section{F The Claimants' January Response to the Government}

After the FSA was enacted, in January 2005, the Claimants responded to the Government's September submissions and briefed the Committee on the substance of the differences between the FS Bill and the FSA. They argued that the effect of the discrimination under the FSA was in fact worse given that amendments to the FS Bill had tightened the tests to establish TCRs. The Claimants also augmented their submissions on the grounds for invoking the early warning and urgent action procedures: we submitted that it is appropriate for the Committee to respond at the first available opportunity on legislation that discriminates racially; and that New Zealand's legislative process is clearly inadequate to ensure that legislation does not discriminate.

\section{G The Government's February Written Submissions}

The Claimants received the Government's submissions on 17 February 2005, only five working days before the Claimants' in-person meeting with the Committee. The Committee received them on 16 February 2005, two working days before the Committee began its February/March meeting. The Government addressed, for the first time in some depth, the issue of racial discrimination and justifications, as outlined in the previous section.

\section{H The Claimants' Oral Presentation to the Committee}

Iwi, as non-governmental organisations, do not have standing to appear before, and make formal submissions to, the Committee. Therefore, we met with the Committee for an hour during its lunchbreak on Thursday 24 February 2005. It was a relatively informal occasion within the formal environment of the United Nations Palais Wilson. We began with a mihi, led by kaumatua Huirangi Waikerepuru, which seemed to have a significant impact on the Committee. It highlighted, we think, the depth of Māori feeling on the foreshore and seabed issue. Huirangi stressed the significance of land in Māori culture. We then presented our formal submissions that the FSA breached the Convention. After our presentation, the Committee members made comments and asked questions.

75 New Zealand Government, to the UN Committee on the Elimination of Racial Discrimination, above $\mathrm{n} 73$.

76 New Zealand Government, to the UN Committee on the Elimination of Racial Discrimination, above $\mathrm{n} 73$. 
For example, the Committee member from the United States was most concerned with the lack of guaranteed redress under the FSA and legislative curtailment of cases before the courts. ${ }^{77}$

\section{The Government's Oral Presentation to the Committee}

On the following day, 25 February 2005, the Government had a three-hour formal session with the Committee. Its submissions were presented by the Permanent Representative, a senior official from the Department of Prime Minister and Cabinet (DPMC), a Crown Law representative and the First Secretary in New Zealand's Geneva-based mission.

The Chair of the Committee's Early Warning and Urgent Action Working Group, Ms JanuaryBardill, introduced the session, detailing the process that had been followed thus far. ${ }^{78}$ Interestingly, she indicated that the Committee had been under the impression that the Government had undertaken not to enact the FS Bill until the Committee had the opportunity to review it during that session, which the Permanent Representative denied. ${ }^{79}$

Professor Thornberry, the former Committee Special Rapporteur on New Zealand, led the Committee's questions and comments to the Government. While presented in polite "United Nations speak", they were relatively 'hard-hitting' and illustrated Professor Thornberry's intimate knowledge of Ngati Apa, the process leading to the enactment of the FSA, including the Waitangi Tribunal Report, and the effect of the FSA on Māori customary title under the TTWMA and common law rights. In summary, Professor Thornberry: ${ }^{80}$

- $\quad$ commented on the "very, very rapid legislative response" to Ngati Apa;

- $\quad$ questioned whether the Government's reliance on Ninety-Mile Beach was optimistic given that it held that Māori aboriginal title in the foreshore and seabed could be extinguished by implication;

- $\quad$ suggested that Canada can live with uncertainty resulting from unextinguished aboriginal title;

77 Statement by Mr Boyd, Member of the UN Committee on the Elimination of Racial Discrimination, to the New Zealand Government (Geneva, 24 February 2005) Claire Charters' meeting notes.

78 Statement by Ms January Bardill, Chairperson of the UN Committee on the Elimination of Racial Discrimination's Early Warning and Urgent Action Working Group, to the New Zealand Government (Geneva, 25 February 2005) Claire Charters' meeting notes.

79 Statement by Ms January Bardill, above n 78

80 Comments by Professor Thornberry, Member of the UN Committee on the Elimination of Racial Discrimination, to the New Zealand Government (Geneva, 25 February 2005) Claire Charters' meeting notes. 
- $\quad$ noted the Waitangi Tribunal's comment that the Government's policy on the foreshore and seabed places most of the uncertainty on Māori;

- $\quad$ suggested that the FSA promises weak rights for Māori;

- concluded that the FSA's protection of sacred sites was insecure as it is based on ministerial discretion;

- $\quad$ stressed that under the FSA the Māori Land Court and the High Court lose their jurisdiction to effectively recognise Māori territorial interests in the foreshore and seabed;

- commented that the replacement regime only provides for the possibility of the establishment of a reserve or redress for the extinguishment of Māori territorial interests;

- noted that under the Convention and international law, customary title is entitled to equal respect;

- concluded that the tests in the FSA for establishing customary rights are stringent and seem to "freeze" them in time; and

- $\quad$ highlighted that human rights treaty body jurisprudence requires that indigenous peoples participate in decisions affecting them.

The questions and comments from the other Committee members were of a similar tenor, although some were clearly focused on bigger picture issues such as the relationship between Māori and non-Māori more generally in New Zealand. Mr Aboul-Nasr, for example, asked the Permanent Representative if he represented all New Zealanders, Māori and non-Māori, equally and Ms January-Bardill questioned whether the FSA was the Government's response to a public "backlash" against perceived special treatment of Māori. ${ }^{81} \mathrm{Mr}$ Cali Tzay suggested that the Māori Members of Parliament may be beholden to party political pressures and, as a result, may not represent a Māori view of the FSA. ${ }^{82}$

The Government's Wellington-based officials responded to the Committee's questions, possibly because they had a more in-depth understanding of the FSA than the New Zealand diplomats. On the issue of discrimination between private titles and Māori territorial interests, the Government noted that the quantity of freehold titles in the foreshore and seabed is modest and mostly resulted

81 Comments by Mr Aboul-Nasr, Member of the UN Committee on the Elimination of Racial Discrimination to the New Zealand Government (Geneva, 25 February 2005) Claire Charters' meeting notes and comments by Ms January Bardill, Chairperson of the UN Committee on the Elimination of Racial Discrimination's Early Warning and Urgent Action Working Group, to the New Zealand Government (Geneva, 25 February 2005) Claire Charters' meeting notes.

82 Comments by Mr Cali-Tzay, Member of the UN Committee on the Elimination of Racial Discrimination, to the New Zealand Government (Geneva, 25 February 2005) Claire Charters' meeting notes. 
from erosion. In this regard, the private titles did not pose the same level of uncertainty for the Government as the potential Māori territorial interests. Finally, it stressed the allocation of 20 per cent of marine farming to Māori under the Māori Commercial Aquaculture Claims Settlement Act 2004.

Professor Thornberry in his closing comments noted that the foreshore and seabed issue raised general questions about the relationship between Western influenced legal systems and indigenous customary law. ${ }^{83}$ The Permanent Representative, in his concluding comments, stated that the Government appreciated the opportunity to engage in dialogue with the Committee and stressed New Zealand's staunch commitment to human rights. ${ }^{84}$

When the formal session with the New Zealand Government ended, it became clear that the Permanent Representative was concerned that we, as the advocates for the Claimants, would have a further opportunity to present oral submissions to the Committee. Indeed, this was the only question he had for us. Professor Thornberry, who witnessed the exchange, seemed somewhat perplexed that these were the only words he addressed to us.

\section{$J$ Continued Lobbying by the Claimants}

We did not have another session with all the Committee members. However, we discovered, by loitering around the meeting room, that Committee members would approach us with specific questions during their lunch-hour or morning and afternoon teas. This provided us with a unique opportunity to build upon our submissions.

Over the following weekend we prepared a one-page response to the New Zealand Government's submissions, which we gave to the Committee members on the morning of Monday 28 February $2005 .{ }^{85}$ With the exception of a paragraph on the appropriate Committee response to the FSA, it did not introduce any new substantive arguments. We felt fairly confident, from the nature of the Committee members' questions and comments to the Government during the Friday formal session, that they had understood our submissions and that the Government's oral submissions did not substantially undermine our arguments. However, given that the Government had created the impression that the moratorium on marine farming resulted from Ngati Apa, we pointed out that it had been in place well before the Court of Appeal decided Ngati Apa. Similarly, we highlighted that the fisheries settlement, which the Government had cited positively, was

83 Comments by Professor Thornberry, above $\mathrm{n} 80$.

84 Statement by Mr Tim Caughley, New Zealand Permanent Representative to the United Nations, to the UN Committee on the Elimination of Racial Discrimination (Geneva, 25 February 2005) Claire Charters' meeting notes.

85 Te Runanga o Ngai Tahu, Treaty Tribes Coalition and the Taranaki Māori Trust Board to the UN Committee on the Elimination of Racial Discrimination "Response to New Zealand's Submissions" (28 February 2005) Submission. 
unrelated to the foreshore and seabed issue. In response to comments by Professor Thornberry, we suggested that the Committee should clearly state that the FSA is discriminatory as a lesser finding could be ignored by New Zealand and noted that the appropriate remedy was a request to the Government that it enter into negotiations with Māori to seek agreement as to how to eliminate the racially discriminatory aspects of the FSA.

\section{K Last-Minute Advocacy}

We sensed on the following Monday morning that some Committee members were concerned about the exact remedy they should suggest, and when. We became apprehensive that the Committee might hold off on making a decision until after it heard New Zealand's next state report. In response, we sent the Committee a further email to stress the importance of it making a decision of discrimination immediately. ${ }^{86}$ In particular, we suggested that difficult questions of appropriate relief should not interfere with the substantive finding of whether or not the FSA discriminates, and that the most important relief was a finding of discrimination. Delaying any Committee response, we argued, would only exacerbate the discrimination under the FSA as the longer it remained unchallenged, the more entrenched the discrimination would become. We again recommended that the Committee suggest the Government enter into negotiations with Māori to amend the FSA.

\section{Additional Government Submission}

The Government provided the Committee with further information. The Permanent Representative wrote to the Committee members on Monday 28 February 2005 indicating its willingness to address the questions it had not had the time to answer on the previous Friday in writing. ${ }^{87}$ It also sought clarification on the procedure the Committee was adopting suggesting that the Friday dialogue was more akin to that which occurs in the state reporting process than under the "narrower early warning and urgent action procedure". ${ }^{88}$ Interestingly, the Government seemed to suggest again that the Committee should not utilise its early warning and urgent action procedure. ${ }^{89}$

86 Claire Charters, Advocate for Te Runanga o Ngai Tahu and the Treaty Tribes Coalition, to Professor Thornberry, Member of the UN Committee on the Elimination of Racial Discrimination, and Nathalie Prouvez, Secretary to the UN Committee on the Elimination of Racial Discrimination (4 March 2005) Email.

87 Tim Caughley, New Zealand Permanent Representative to the United Nations, to Mr Yutzis, Chair of the UN Committee on the Elimination of Racial Discrimination (28 February 2005) Letter.

88 Tim Caughley, New Zealand Permanent Representative to the United Nations, to Mr Yutzis, Chair of the UN Committee on the Elimination of Racial Discrimination (28 February 2005) Letter.

89 Tim Caughley wrote: "Secondly, it would be helpful for the preparation of any written answers posed by your Committee if the Committee could provide a more precise indication of the nature of the procedure currently in operation and the next steps. During Friday's hearing there were intimations that suggested that the development of a general procedure for dealing with situations such as the current one is still evolving. We had that impression too, that our dialogue was as much, perhaps more, akin to that which occurs during 
In response, the Committee's Chairperson invited the Government to meet again with the Committee and respond to specific questions. ${ }^{90}$ The Chairperson also made it clear that the procedure followed was that of the early warning and urgent action..$^{91}$

The Government declined the invitation to appear again before the Committee. ${ }^{92}$ Instead, it forwarded its answers to specific questions to the Committee on 9 March 2005. ${ }^{93}$ The Crown's substantive arguments remained the same, although some elements of those final submissions deserve specific mention. Despite the level of disagreement, especially between Māori and the Crown, surrounding the interpretation of the Treaty of Waitangi, the Government asserted that "the recognition of equal rights for Māori and special protection for Māori interests on the one hand and the creation of a single legal system on the other are at the heart of the commitments exchanged under Treaty of Waitangi of $1840 . " 94$ Clearly this interpretation of the Treaty of Waitangi downplays the significance of the article 2 guarantee of tino rangatiratanga (self-determination) as well as, the common law recognition of Māori customary law after $1840 .{ }^{95}$ Perhaps the purpose of this submission was to suggest that Māori gave up any right to recognition of their customary law domestically under the Treaty of Waitangi despite international legal recognition of indigenous law. Irrespective, it is clearly a dubious comment to make. The Government also implied that the level of Māori rejection of the FSA was exaggerated by the Claimants as the "Māori MPs reflect a broader constituency" than those organisations. ${ }^{96}$ This is similarly controversial given the level of Māori rejection of the FSA.

the presentation of periodic reports than to the narrower early warning and urgent action procedure ...": Tim Caughley, New Zealand Permanent Representative to the United Nations, to Mr Yutzis, Chair of the UN Committee on the Elimination of Racial Discrimination (28 February 2005) Letter.

90 Mr Yutzis, Chair of the UN Committee on the Elimination of Racial Discrimination, to Tim Caughley, New Zealand Permanent Representative to the United Nations (2 March 2005) Letter.

91 Mr Yutzis, Chair of the UN Committee on the Elimination of Racial Discrimination, to Tim Caughley, New Zealand Permanent Representative to the United Nations (2 March 2005) Letter.

92 Tim Caughley, New Zealand Permanent Representative to the United Nations, to Mr Yutzis, Chair of the UN Committee on the Elimination of Racial Discrimination (3 March 2005) Letter.

93 Tim Caughley, New Zealand Permanent Representative to the United Nations, to Mr Yutzis, Chair of the UN Committee on the Elimination of Racial Discrimination (9 March 2005) Letter.

94 Tim Caughley, New Zealand Permanent Representative to the United Nations, to Mr Yutzis, Chair of the UN Committee on the Elimination of Racial Discrimination (9 March 2005) Letter.

95 Public Trustee v Loasby(1908) 27 NZLR 801 (SC); $R$ v Symonds (1847) NZPCC 387 (SC).

96 Tim Caughley, New Zealand Permanent Representative to the United Nations, to Mr Yutzis, Chair of the UN Committee on the Elimination of Racial Discrimination (9 March 2005) Letter. 


\section{$V$ THE CERD DECISION AND ITS CONSEQUENCES}

\section{$A$ The CERD Decision}

The CERD Decision is, like other decisions utilising the early warning and urgent action procedure, succinct. ${ }^{97}$ It is reflective, however, of the arguments made by the Claimants and the Government, and especially the comments and questions posed by the Committee members. The CERD Decision makes more sense when placed in the context of the extensive arguments advanced during the advocacy process.

First, the Committee notes that it has reviewed the compatibility of the FSA with the Convention under its early warning and urgent action procedure taking into account the submissions it received and its General Recommendation on Indigenous Peoples. ${ }^{98}$

The CERD Decision then expresses the Committee's concern with "the political atmosphere that developed in New Zealand" following Ngati Apa and hopes that "all actors in New Zealand will refrain from exploiting racial tensions for their own political advantage."${ }^{199}$ These comments could relate not only to state parties' obligations under the Convention but also indicate that the deteriorating political environment in New Zealand was a reason for it utilising its early warning procedure. It seems clear that the Committee is referring to comments made by political parties on broader Māori issues, referred to earlier, that the Claimants highlighted to argue that it was appropriate for the Committee to invoke its early warning procedure in relation to the FS Bill.

The Committee reiterates its concern, expressed also during its session with the Government, with "the apparent haste with which the legislation was enacted and that insufficient consideration may have been given to alternative responses to the Ngati Apa decision which might have accommodated Māori rights within a framework more acceptable to both the Māori and all other New Zealanders. ${ }^{" 100}$ Clearly, this comment is consistent with the Claimants' submissions that there were rational alternatives to the FSA that would not have discriminated against Māori.

On process, the Committee "regrets that the processes of consultation did not appreciably narrow the differences between the various parties on the issue". ${ }^{101}$ Further, it "notes the scale of opposition to the legislation among the group most affected by its provisions - the Māori - and their

97 United Nations Committee on the Elimination of All Forms of Racial Discrimination "Decision 1(66): New Zealand Foreshore and Seabed Act 2004" (11 March 2005) CERD/C/66/NZL/Dec.1. The decision is reproduced as Appendix 1 to this article.

98 "Decision 1(66): New Zealand Foreshore and Seabed Act 2004", above n 97, para 1.

"Decision 1(66): New Zealand Foreshore and Seabed Act 2004", above n 97, para 3.

100 "Decision 1(66): New Zealand Foreshore and Seabed Act 2004", above n 97, para 4.

101 "Decision 1(66): New Zealand Foreshore and Seabed Act 2004", above n 97, para 4. 
very strong perception that the legislation discriminates against them."102 The concern with insufficient consultation and lack of Māori consent is in line with the Committee's General Recommendation on Indigenous Peoples and, specifically, the requirement that states "ensure that members of indigenous peoples have equal rights in respect of effective participation in public life and that no decisions directly relating to their rights and interests are taken without their informed consent." 103

The most damning and significant paragraph of the Committee's CERD Decision is this: ${ }^{104}$

Bearing in mind the complexity of the issues involved, the legislation appears to the Committee, on balance, to contain discriminatory aspects against the Māori, in particular in its extinguishment of the possibility of establishing Māori customary title over the foreshore and seabed and its failure to provide a guaranteed right of redress, notwithstanding the State party's obligations under articles 5 and 6 of the Convention.

The specific mention of articles 5 and 6 of the Convention suggests that the FSA breaches the Convention. In particular, the Committee is concerned, it seems clear, with the FSA's removal of the right of Māori to seek a customary title in the foreshore and seabed through the Māori Land Court, exercising its statutory jurisidiction under TTWMA, and, the High Court, exercising its common law native title jurisidicton. That the Committee isolated the failure to provide redress is not surprising. As we have seen, the General Recommendation on Indigenous Peoples requires at least compensation where a state takes indigenous land. ${ }^{105}$

It should be noted that the Committee's finding of discrimination is semantically muted. It uses the word "appears" rather than "is". ${ }^{106}$ This reflects that the Committee endeavours to offer constructive advice to states diplomatically. It is consistent, however, with the view that the FSA creates, as one Committee member stated during the Government's formal session with the Committee, "an unfavourable optic". 107

Interestingly, the Committee seems to have been particularly influenced by the Claimants' submissions in relation to appropriate relief which were made in the final two written

102 "Decision 1(66): New Zealand Foreshore and Seabed Act 2004", above n 97, para 5.

103 UN Committee on the Elimination of Racial Discrimination "General Recommendation XXIII: Indigenous Peoples" (18 August 1997) A/52/18, annex V.

104 "Decision 1(66): New Zealand Foreshore and Seabed Act 2004", above n 97, para 6.

105 "General Recommendation XXIII: Indigenous Peoples", above n 13.

106 "Decision 1(66): New Zealand Foreshore and Seabed Act 2004", above n 97, para 6.

107 Comments by Mr Boyd, Member of the UN Committee on the Elimination of Racial Discrimination to the New Zealand Government (Geneva, 25 February 2005) Claire Charters' meeting notes. 
communications we had with the Committee. It first "acknowledges with appreciation the State party's tradition of negotiation with the Māori on all matters concerning them" and then urges: ${ }^{108}$

the State party, in a spirit of goodwill and in accordance with the ideals of the Waitangi Treaty, to

resume a dialogue with the Māori community with regard to legislation in order to seek ways of

lessening its discriminatory effects, including where necessary through legislative amendment.

The Committee's recommendation to the Government to make legislative amendments, and the reference to the "discriminatory effects" of the FSA, illustrates that, despite the word "appears" in the previous paragraph of the CERD Decision, the Committee is clearly of the view that the FSA is discriminatory.

In the following paragraph, the Committee requests New Zealand to "take steps to minimise any negative effects [of the FSA], especially by flexible application of the legislation and by broadening the scope of redress available to the Māori."109

Finally, the Committee requests New Zealand to include full information on the implementation of the FSA in its next report, due in December 2005, indicating its intention to continue monitoring the FSA's compliance with Convention.

\section{$B$ The Government's Response to the CERD Decision}

At the centre of the New Zealand Government's response was a simple "did not". ${ }^{110}$ The Prime Minister stated in an interview that "I have to say there is nothing in that decision that finds that New Zealand was in breach of any international convention at all."111 It was followed shortly after by a "won't change it": and "The legislation was passed, it has good support from the great majority of New Zealand and the legislation stands". ${ }^{112}$ The response got particularly nasty when the Prime Minister denigrated the Committee by saying, as mentioned in the introduction, that it is "on the outer edges of the UN system" and implied that the Claimants did not know what they were doing in seeking United Nations censure of the FSA. She stated "[w]ell, I think I have a somewhat better understanding of the UN system than they do."113

108 "Decision 1(66): New Zealand Foreshore and Seabed Act 2004", above n 97, para 7.

109 "Decision 1(66): New Zealand Foreshore and Seabed Act 2004", above n 97, para 8.

110 A number of these phrases are taken from Devika Hovell "The Sovereignty Stratagem: Australia's Response to UN Human Rights Treaty Bodies" (2003) 28 Alternative Law Journal 297. They illustrate the similarity between Australia's response to UN human rights treaty bodies and New Zealand's.

111 Interview with Rt Hon Helen Clark, above n 5.

112 Interview with Rt Hon Helen Clark, above n 5.

113 Interview with Rt Hon Helen Clark, above n 5. 
We were surprised by the Government's response to the CERD Decision. We expected the Government to come out strongly against it. However, we did not anticipate that it would misrepresent the substance of the decision or attack the Committee and the Claimants.

One reason for our surprise was that it is so absolutely inconsistent with New Zealand's official rhetoric on human rights, as evidenced by the Permanent Representative's above-mentioned comment that New Zealand is a strong defender of human rights. By rejecting the CERD Decision it is sending a message to other states that it is acceptable to ignore the Committee's decisions. When one considers that the Committee also utilised its early warning and urgent action procedure to comment on the situation in Dafur, Sudan on the same day as it issued its CERD Decision, New Zealand's response is clearly of grave concern.

\section{Next Steps}

The findings of the Committee are not enforceable in New Zealand. Their "sanction" is, in this sense, moral only. Nevertheless, we have not heard the last of the CERD Decision. Most importantly, it will be the subject of New Zealand's next state report to the Committee and the Committee's concluding observations on that report. The Committee has clearly stated that it will keep a watching brief on the issue. ${ }^{114}$ It can be assumed that a shadow-report will be submitted and that the Committee members will receive all the press reports detailing the Government's response. We anticipate that the Committee will be critical of New Zealand's reaction to its CERD Decision.

Other human rights treaty bodies will also be aware of the Committee's CERD Decision and we expect that they will, where relevant, also express concern in observations on New Zealand's state reports. This is especially true of the UNHRC as the ICCPR includes the right to freedom from discrimination. ${ }^{115}$ There is also the possibility that Māori individuals may bring an individual communication to the UNHRC alleging the FSA breaches the right to freedom from discrimination and the right to enjoy culture.

In the light of the continued pressure that will be applied to New Zealand by international human rights bodies, one option for the Government is to indeed start a dialogue with Māori as recommended by the Committee. A different option, although not necessarily compliant with the CERD Decision, is to establish a unique parliamentary committee to examine the FSA in the light of the CERD Decision. Yet another option would be to seek re-review by an existing select committee (albeit not the Fisheries and Other Sea Related Legislation Committee). There is precedent for this type of response. Australia, renowned for its rejection of adverse international human rights bodies' decisions, ${ }^{116}$ established a parliamentary joint committee to consider whether amendments to the

114 "Decision 1(66): New Zealand Foreshore and Seabed Act 2004", above n 97, para 9.

115 International Covenant on Civil and Political Rights, above n 52.

116 See Hovell, above n 110, 297. 
Native Title Amendment Act 1998 were necessary for Australia to comply with its international obligations post the Australian Native Title Decision. ${ }^{117}$ With elections looming, we do not anticipate any such governmental action in the short-term. However, Māori could certainly lobby for a re-examination of the FSA in the mid to long term.

Whether the FSA will be amended to eliminate its racially discriminatory aspects is, unfortunately, a moot point. Parliament reigns supreme in New Zealand. Irrespective, the CERD Decision sends a strong signal to the Government that the FSA breaches New Zealand's international human rights obligations. It has some real value, also, in vindicating Māori rejection of the FSA.

\section{CONCLUSION}

In conclusion, the road leading to the CERD Decision was a long one. It did not follow preordained procedural rules, as is, it seems, typical when the Committee is utilising its early warning and urgent action procedure. The Committee clearly seeks to retain the flexibility required to assess each situation of alleged escalating racial discrimination on its own terms, focusing on substance rather than form. Nevertheless, contrary to the Prime Minister's suggestion, the process was a robust one. Both the Claimants and the Government had every opportunity to present their case, the Government even turning down the opportunity for a further meeting with the Committee. The arguments were fully fleshed out, and clearly understood by the Committee members, as evidenced in their questions to the Government and the Claimants. The CERD Decision reflects, succinctly, the arguments made in submissions.

117 See Parliament of Australia Joint Committee on Native Title and Aboriginal and Torres Strait Islander Land Fund "Sixteenth Report: Consistency of the Native Title Amendment Act 1998 with Australia's International Obligations under the Convention on the Elimination of All Forms of Racial Discrimination (CERD)" (Canberra, 2000). 
UNITED

NATIONS

$\begin{array}{lll}\text { International Convention } & \begin{array}{l}\text { Distr. } \\ \text { GENERAL } \\ \text { on the Elimination } \\ \text { of all Forms of } \\ \text { Racial Discrimination }\end{array} & \begin{array}{l}\text { Original: ENGLISH } \\ \text { UNEDITED VERSION }\end{array} \\ \end{array}$

COMMITTEE ON THE ELIMINATION

OF RACIAL DISCRIMINATION

Sixty-sixth session

21 February - 11 March 2005

\section{Decision 1 (66)}

New Zealand Foreshore and Seabed Act 2004

1. The Committee has reviewed, under its Early-Warning and Urgent Action Procedure, the compatibility of the New Zealand Foreshore and Seabed Act 2004 with the provisions of the International Convention on the Elimination of All Forms of Racial Discrimination in the light of information received both from the Government of New Zealand and a number of Māori non-governmental organizations and taking into account its General Recommendation No. XXIII on indigenous peoples.

2. The Committee appreciates having had the opportunity to engage in a constructive dialogue with the State party at the Committee's 1680th meeting and the State party's written and oral responses to its requests for information related to the legislation, including those submitted on 17 February and 9 March 2005.

3. The Committee remains concerned about the political atmosphere that developed in New Zealand following the Court of Appeal's decision in the Ngati Apa case which provided the backdrop to the drafting and enactment of the legislation. Recalling the State party's obligations under article 2(1)(d) and article 4 of the Convention, it hopes that all actors in New Zealand will refrain from 
exploiting racial tensions for their own political advantage.

4. The Committee, while noting the explanation offered by the State party, is concerned at the apparent haste with which the legislation was enacted and that insufficient consideration may have been given to alternative responses to the Ngati Apa decision which might have accommodated Māori rights within a framework more acceptable to both the Māori and all other New Zealanders. In this regard, the Committee regrets that the processes of consultation did not appreciably narrow the differences between the various parties on this issue.

5. The Committee notes the scale of opposition to the legislation amongst the group most directly affected by its provisions - the Māori-and their very strong perception that the legislation discriminates against them.

6. Bearing in mind the complexity of the issues involved, the legislation appears to the Committee, on balance, to contain discriminatory aspects against the Māori, in particular in its extinguishment of the possibility of establishing Māori customary title over the foreshore and seabed and its failure to provide a guaranteed right of redress, notwithstanding the State party's obligations under articles 5 and 6 of the Convention.

7. The Committee acknowledges with appreciation the State party's tradition of negotiation with the Māori on all matters concerning them and urges the State party, in a spirit of goodwill and in accordance with the ideals of the Waitangi Treaty, to resume a dialogue with the Māori community with regard to the legislation in order to seek ways of lessening its discriminatory effects, including where necessary through legislative amendment.

8. The Committee requests the State party to monitor closely the implementation of the Foreshore and Seabed Act, its impact on the Māori population and the developing state of race relations in New Zealand and to take steps to minimize any negative effects, especially by way of a flexible application of the legislation and by broadening the scope of redress available to the Māori.

9. The Committee has noted with satisfaction the State party's intention to submit its fifteenth periodic report by the end of 2005, and requests the State party to include full information on the state of implementation of the Foreshore and Seabed Act in the report. 